\title{
Immunological predictors of recurrence in patients with inflammatory bowel disease
}

\author{
JOHN P WRIGHT
}

JP WRIGHT. Immunological predictors of recurrence in patients with inflammatory bowel disease. Can J Gastroenterol 1993; $7(2): 223-225$. The management of patients with inflammatory bowel disease is complicated by the poor correlation between symptoms and prognosis. This is due to the inconsistent and subjective nature of the symptoms of these diseases. Laboratory parameters which reflect the acute phase response offer an objective measure of disease activity and have been used in isolation as well as within clinical indices. The problem is that these parameters do not correlate very well with the indices of clinical activity. To predict disease recurrence it is presumed that an increase in disease activity, at the cellular level, precedes a clinical deterioration. An increase in acute phase proteins in the months before clinical recurrence confirms this supposition. The poor correlation between the acute phase proteins suggests that they may be reacting to different stimuli. Where single parameters are used the orosomucoid, C-reactive protein and $\alpha-1$-antitrypsin levels are the best predictors of clinical relapse of Crohn's disease within the following three months, giving true positive rates of approximately $20 \%$ overall with a sensitivity of approximately $60 \%$. The efficiency of these parameters improves in patients with Crohn's ileocolitis where rates of $27 \%$ and $63 \%$ are found. The less expensive erythrocyte sedimentation rate is almost as useful but is less specific. To improve the predictive ability of the acute phase proteins various indices have been proposed. These indices offer true positive rates of $29 \%$ to $77 \%$. The wide range is probably due to patient selection, differing predictive periods and attack definitions in the orginal reports. In conclusion, the acute phase protein response can be used to predict disease recurrence but further refinement and verification is needed.

Key Words: Crohn's disease, Disease activity, Immunological markers, Recurrence

Facteurs immunologiques de prévisibilité de la récurrence chez les patients atteints de maladie intestinale inflammatoire

RÉSUMÉ: Le traitement des patients qui souffrent de maladie intestinale inflammatoire est compliqué par la faible corrélation entre symptômes et pronostic. Cela est dû à la nature irrégulière et subjective des symptômes de ces maladies. Les paramètres de laboratoire qui reflètent la phase aiguë de la réponse offrent une mesure objective de l'activité de la maladie et ont été utilisés soit isolément, soit avec des indices cliniques. Malheureusement, ces paramètres ne concordent

Gastrointestinal Clinic, Department of Medicine. University of Cape Town and Grootte Schurr Hospital, Republic of South Africa

Correspondence: Professor John P Wright, Gastrointestinal Clinic, Groote Schurr Hospital, Observatory, Republic of South Africa. Telephone (021) 404-3062, Fax (021) 47-0582

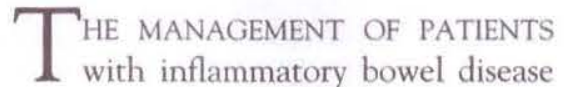
is complicated by the poor correlation between symptoms and prognosis. This is due to the inconsistent and subjective nature of the symptoms of these diseases. In order to quantify more objectively disease severity, various laboratory parameters have been proposed as indicators of current and future clinical activity erythrocyte sedimentation rate (1-3), platelet count $(4,5)$, albumin $(6)$, iron $(7,8)$, C-reactive protein $(1,2,9-11)$, orosomucoids $(1,2,12,13)$ and $\alpha$ - 1 -antitryp$\sin (1,13,14)$. These parameters generally reflect the acute phase response but they are poorly correlated with each other (9), suggesting that they may be reacting to different stimuli (15). In order to predict disease course it is presumed that an increase in disease activity, at the cellular level, precedes a clinical deterioration. An increase in acute phase reactants in the months before clinical recurrence confirms this supposition (9). The specificity of this phenomenon needs to be determined in prospective studies of the ability of the acute phase reactants to predict acute recurrences in a defined population of patients. There is as yet limited published work $(9,10,16)$.

When using the single parameters to predict recurrence a test result will need to be classified as predictive off an attack or not based on a predetermined cut-off value. The normal ranges of the 
pas toujours très bien avec les indices de l'activité clinique. Pour prédire les récidives de la maladie, on présume qu'une augmentation de l'activité de la maladie au niveau cellulaire précède une détérioration clinique. Une augmentation des protéines de la phase aiguë, dans les mois qui précèdent la récidive clinique confirme cette hypothèse. La corrélation faible entre les protéines de phase aiguë suggère qu'elles pourraient réagir à des stimuli différents. Là où les paramètres isolés sont utilisés, les taux de protéines C-réactives orosomucoïdes et d'antitrypsine A-1 sont les meilleurs prédicteurs de la rechute clinique de la maladie de Crohn dans les trois mois qui suivent, ce qui donne des taux positifs vrais d'environ $20 \%$ globalement, avec un degré de sensibilité d'environ $60 \%$. L'efficacité de ces paramètres est encore meilleure chez les patients qui présentent une iléocolite de Crohn où les taux sont de $27 \%$ et de $63 \%$ respectivement. Le taux de sédimentation des érythrocytes, moins cher, est presque aussi utile, mais moins spécifique. Pour améliorer la capacité prédictive des protéines de phase aiguë, divers indices ont été proposés. Ces indices offrent des taux positifs vrais de $29 \%$ à $77 \%$. Leur grande variabilité est probablement due à la sélection des patients, aux différentes périodes visées et à la définition des crises dans les rapports originaux. En conclusion, la réaction des protéines à la phase aiguë peut être utilisée pour prédire les récidives de la maladie, mais il faut procéder à d'autres ajustements et vérifications.

\section{TABLE 1}

Predictive thresholds of acute phase reactants in patients with Crohn's disease

\begin{tabular}{lcc}
\hline Reactant & Predictive threshold & Normal value \\
\hline$\alpha$-l-antitrypsin & $2.75 \mathrm{mg} / \mathrm{mL}$ & $1.1-3.9$ \\
Orosomucoid & $1.2 \mathrm{mg} / \mathrm{mL}$ & $0.4-1.3$ \\
C-reactive protein & $1.5 \mathrm{mg} / \mathrm{dL}$ & 0 \\
Erythrocyte sedimentation rate & $30 \mathrm{~mm} / 1 \mathrm{st}$ hour & $\mathrm{M}<11, \mathrm{~F}<12$ \\
Serum albumin & $35 \mathrm{~g} / \mathrm{L}$ & $35-55$ \\
Serum iron & $10.0 \mathrm{mg} / \mathrm{mL}$ & $8-30$ \\
\hline
\end{tabular}

M Male; F Female

TABLE 2

Predictive statistics of acute phase reactants in patients with Crohn's disease

\begin{tabular}{lcc}
\hline Reactant & True positive (\%) & Sensitivity (\%) \\
\hline$\alpha$-1-antitrypsin & 22 & 67 \\
Orosomucoid & 19 & 58 \\
C-reactive protein & 20 & 58 \\
Erythrocyte sedimentation rate & 20 & 43 \\
Serum albumin & 21 & 11 \\
Serum iron & 18 & 44 \\
\hline
\end{tabular}

parameters that are clinically used do not necessarily reflect the optimum discriminating value when identifying imminent recurrence. The 'receiver operator characteristic' technique has been developed to determine a parameter's cut-off and to compare its effectiveness to other parameters. The theory, interpretation and determination of diagnostic thresholds are described elsewhere (17-19). When multiple parameters are being assessed for predictive ability, discriminant analysis is better suited to the creation of an index.

In a study from Cape Town the prospectively collected data from 3522 visits of 193 patients were analyzed to determine the predictive value of the acute phase reactants. All patients had been clinically inactive (Crohn's disease activity index [20] [CDAI] less than 150) for three consecutive months. If the patient had an acute relapse within the predictive period of three months the patient was with- drawn and only re-entered when there had been no clinical activity (CDAI less than 150) for a further three months (21).

Attacks of Crohn's disease were divided on clinical grounds into three categories.

Inflammatory: Increases diarrhea and abdominal pain with systemic features of inflammation (pyrexia and malaise) with or without a tender abdominal mass.

Obstructive: Severe cramping abdominal pain with or without concomitant vomiting or fluid levels on plain ab. dominal $x$-ray. The patient charac. teristically reports that if the cramps were to be relieved he or she would feel well.

Other: A variety of attack types including Crohn's esophagitis, sudden severe hypoproteinemia with peripheral edema, perforation, hemorrhage and acute perianal disease.

The best predictive cut-off values were calculated with the receiver operator characteristic curve technique (Table 1). Using these cut-off values the orosomucoid, C-reactive protein and $\alpha-1$-antitrypsin levels are the best predictors of clinical relapse of Crohn's disease within the following three months, giving true positive rates of approximately $20 \%$ overall with a sensitivity of approximately $60 \%$ (Table 2). The efficiency of these parameters improves in patients with Crohn's ileocolitis where rates of approximately $27 \%$ and $63 \%$ are found (Table 3 ). The less expensive erythrocyte sedimentation rate is almost as useful but is less sensitive.

These apparently low predictive values must be compared to the underlying prevalence of recurrence of $10 \%$ in the same patient population.

To improve the predictive ability of the acute phase proteins a combination index is proposed (22). A combination of $\alpha$-1-antitrypsin and orosomucoid offers a true positive rate of $29 \%$ and a sensitivity of $62 \%$. In patients with ileocolitis this increases to $38 \%$ and $64 \%$, respectively.

A combination predictive index was reported by Brignola et al (16). They followed 41 patients with Crohn's dis- 
ease for up to 18 months. The recurrence rate was calculated after nine and 18 months and the predictive value of the acute phase reactants, which had been estimated at the start of the study, assessed. A discriminant analysis suggested an index consisting of $\alpha-1$. glycoprotein, $\alpha$-2-globulin and erythrocyte sedimentation rate. With this index an excellent true positive rate of $77 \%$ at nine months and $100 \%$ at 18 months was reported. The sensitivity was $62 \%$ and $71 \%$, respectively. The patients in this study were entered only if they had had no treatment for at least six months. As only 17 patients relapsed during the 18 month study the relapse rate appears to be of the order of 12 per year (ie, $29 \%$ ). If the six months before entry (when the patients were clinically well) are included, the relapse rate for the trial group falls to

\section{REFERENCES}

1. André $\mathrm{C}$, Decos L, Landais $\mathrm{P}$, Fermanian J. Assessment of appropriate laboratory measurements to supplement the Crohn's disease activity index. Gut 1981;22:571-4.

2. Fagan EA, Dyck RF, Maton PN, et al. Serum levels of $\mathrm{C}$-reactive protein in Crohn's disease and ulcerative colitis. Eur J Clin Invest 1982;12:351-60.

3. Sachar DB, Smith H, Chan S, Cohen LB, Lichtiger S, Messer J. Erythrocyte sedimentation rate as a measure of clinical activity in inflammatory bowel disease. J Chin Gastroenterol 1986:8:647-50.

4. Hall JC. Platelet count in patients with Crohn's disease. Br Med ] 1983;286:1895-6. (Lett)

5. Harries AD, Fitzsimons E, Fifield R, Dew MJ, Rhodes J. Phatelet count: A simple measure of activity in Crohn's disease. Br Med J 1983;286:1476.

6. Cooke WT, Prior P. Determining disease activitý in inflammatory bowel disease. J Clin Gastroenterol 1984;6:17-25.

7. Wright JP. Predicting relapses of Crohn's disease by means of serum iron changes. 8th World Congress of Gastroenterology, Sao Paulo, Brazil, 1986.

8. Talstad I, Gjone E. The disease activity of ulcerative colitis and Crohn's disease. Gut 1976;11:403-8.

TABLE 3

Effect of disease extent on predictive statistics of acute phase reactants

\begin{tabular}{|c|c|c|c|c|c|c|}
\hline \multirow[b]{2}{*}{ Reactant } & \multicolumn{3}{|c|}{ True positive (\%) } & \multicolumn{3}{|c|}{ Sensitivity (\%) } \\
\hline & Ileitis & $\begin{array}{l}\text { Ileo- } \\
\text { colitis }\end{array}$ & Colitis & lieitis & $\begin{array}{l}\text { Ileo- } \\
\text { colitis }\end{array}$ & Colitis \\
\hline$\alpha$-1-antitrypsin & 15 & 28 & 21 & 51 & 69 & 75 \\
\hline Orosomucoid & 16 & 26 & 14 & 60 & 59 & 50 \\
\hline C-reactive protein & 18 & 27 & 12 & 55 & 62 & 50 \\
\hline $\begin{array}{l}\text { Erythrocyte } \\
\text { sedimentation rate }\end{array}$ & 18 & 30 & 11 & 35 & 49 & 40 \\
\hline Serum albumin & 13 & 37 & 42 & 12 & 10 & 9 \\
\hline Serum iron & 15 & 24 & 14 & 36 & 45 & 78 \\
\hline
\end{tabular}

$20 \%$. This is lower than that reported from Denmark and Cape Town where a relapse rate of approximately $50 \%$ per year is seen $(23,24)$. The wide range of results found by the predictive indices is probably due to patient selection, different attack definitions and predictive periods in the original reports.

9. Wright JP, Alp MN, Young GO, Tigler-Wybrandi N. Predictors of acute relapse of Crohn's disase. Dig Dis Sci 1987:32:164-70.

10. André C, Decos L, Vignal J, Gillon JC. Reactive protein as a predictor of relapse in asymptomatic patents with Crohn's disease. Scott Med ] 1983;28:26-9.

11. Campbell CA, Walker-Sniith JA Hindocha P, Adinolfi M. Acute phase proteins in chronic inflammatoty bowel disease in childhood. ] Paediatr Gastroenterol Nutr 1982;2:193-200.

12. Cooke WT, Fowler DC, Cox EV, Gaddie R, Meynell MJ. The clinical significance of seromucoids in regional ileitis and ulcerative colitis. Gastroenterology 1958;34:910-9.

13. Weeke B, Jarnum S. Serum concentration of 19 serum proteins in Crohn's disease and ulcerative colitis. Gut 1971:12:297-302.

14. Klasen EC, Biemond I, Weterman IT. $\alpha-1$-antitrypsin and phenotypes in Crohn's disease in the Netherlands. Gut 1980;21:840-2.

15. Richter MB, Coughlan RJ, Panayi GS, Gordon Y. Is there more than one signal for an acute response? J Rheumatol 1985:12;1048-52.

16. Brignola C, Campieri M, Bazzocchi G, Farruggia P, Tragnone A, Lanfranchi GA. A laboratory index for predicting
In conclusion, the acute phase response mirrors disease activity as measured by the acute phase proteins and although each appears to measure a different aspect of the responses they may be clinically useful in predicting clinical recurrence. Further refinement and verification is needed, however.

relapse in asymptomatic patients with Crohn's disease. Gastroenterology 1986;91:1490-4.

17. Lusted LB. Decision making studies in patient management. N Engl J Med 1971;284:416-24

18. Hanley JA, McBeil BJ. The meaning and use of the area under a receiver operating characteristic (ROC) curve. Radiology 1982;143:29.36.

19. McClish DK. Comparing the areas under more than two independent ROC curves. Med Decis Making 1987;7:149-55.

20. Best WR, Becktel JM, Singleton JW, Kern F. Development of a Crohn's disease activity index. Gastroenterology 1976:70:439-44.

21. Wright JP. The differences in the ability of acute phase reactants to predict acute relapses of Crohn's diseases. S Afr Med J 1988;73:666.

22. Wright JP. Towards a predictive index for Crohn's disease relapses. S Afr Med J 1985;68:522.

23. O'Keefe EA, Wright JP, Froggat J, Zabow D. A medium follow-up of Crohn's disease in Cape Town. S Afr Med I 1989;76:139-41.

24. Binder V, Hendriksen C, Kreiner S. Prognosis in Crohn's disease - based on results from a regional patient group from the county of Copenhagen. Gut $1985 ; 26: 146-50$. 


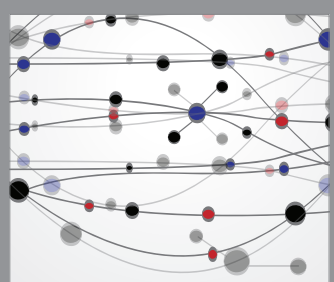

The Scientific World Journal
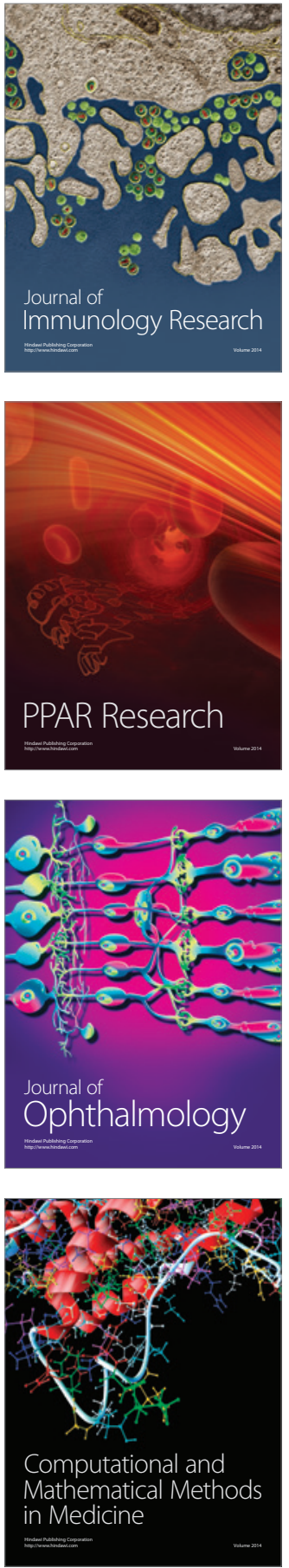

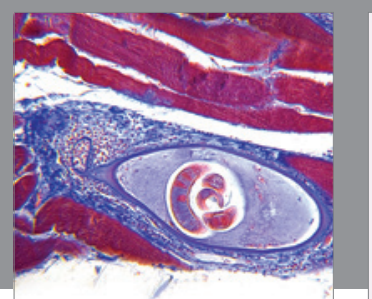

Gastroenterology Research and Practice

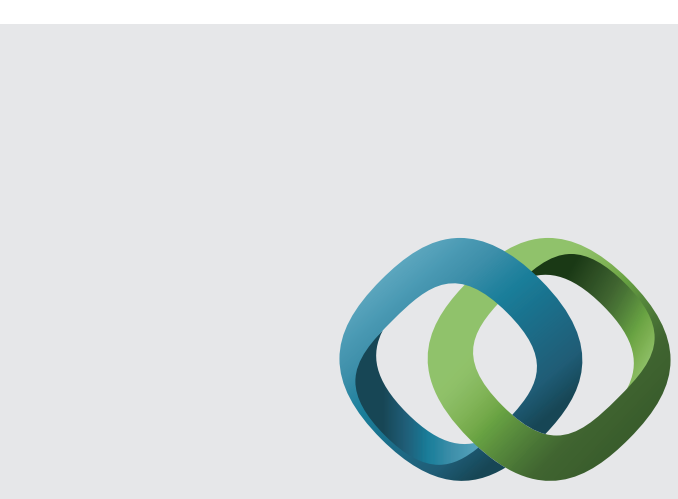

\section{Hindawi}

Submit your manuscripts at

http://www.hindawi.com
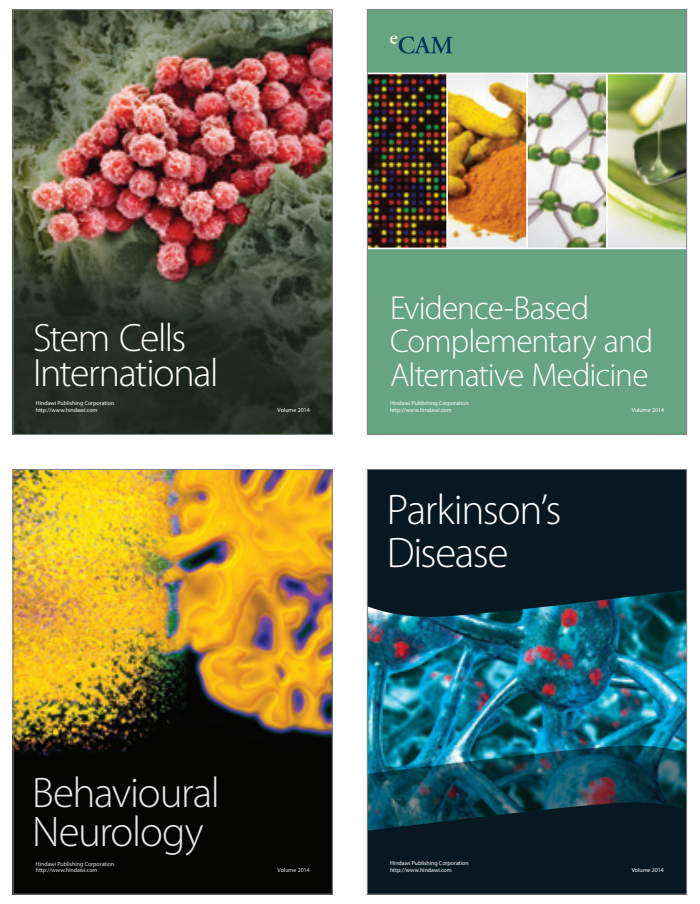
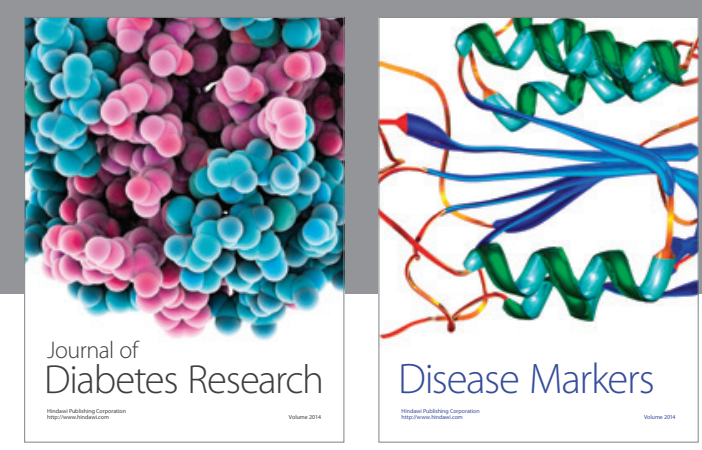

Disease Markers
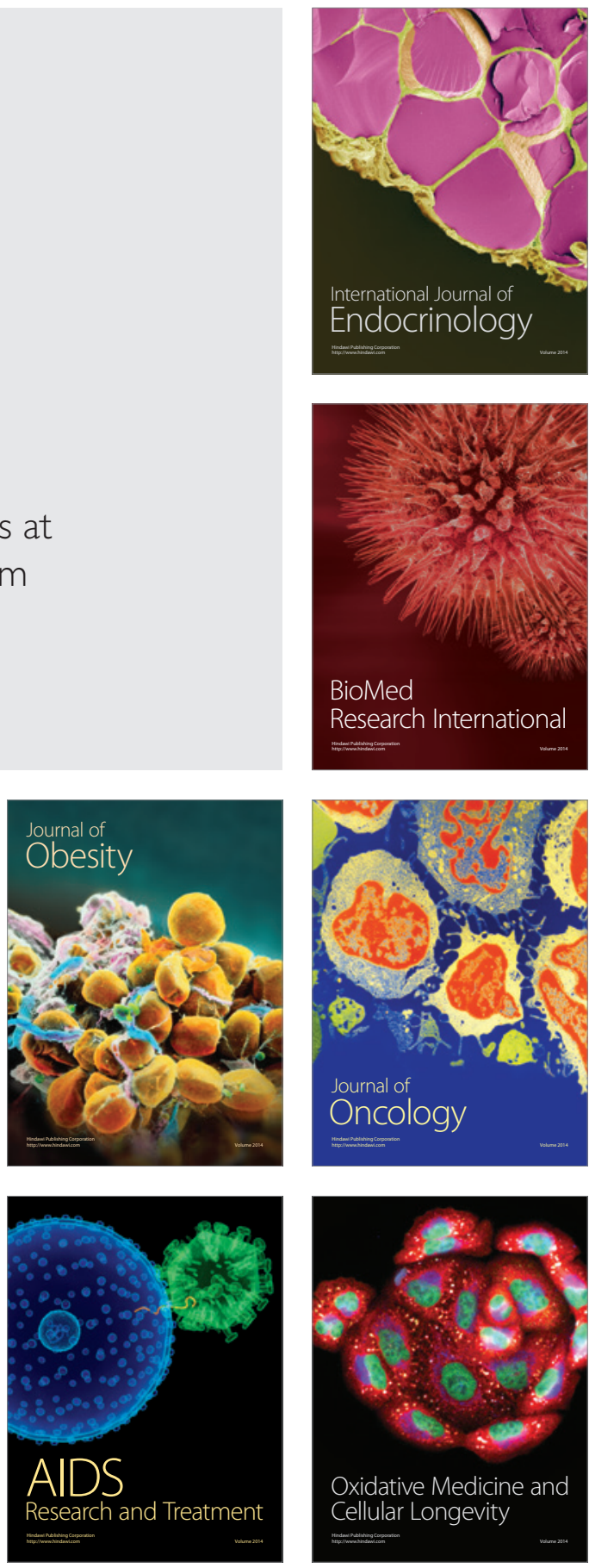